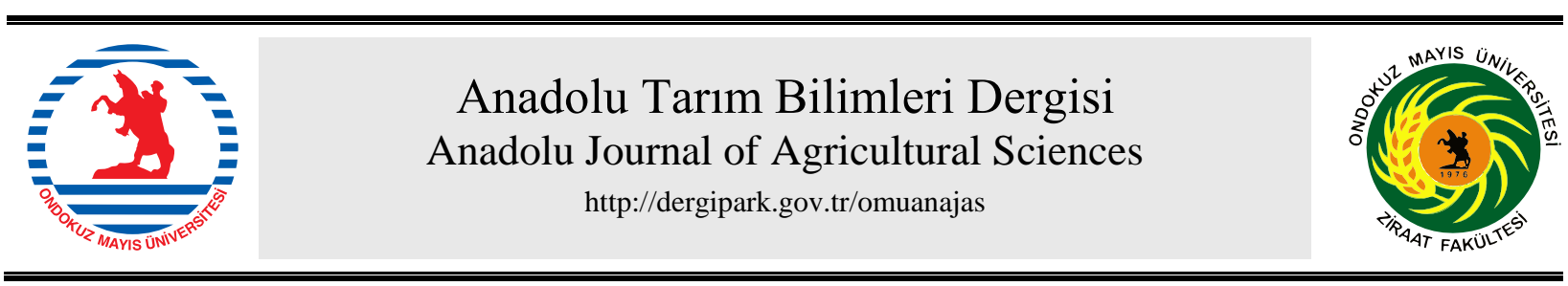

Araştırma/Research

Anadolu Tarım Bilim. Derg./Anadolu J Agr Sci, 36 (2021) ISSN: 1308-8750 (Print) 1308-8769 (Online) doi: 10.7161/omuanajas.734650

\title{
Kırsal Kalkınma Projelerinde Hibe Programından Yararlanmayı Etkileyen Faktörlerin Değerlendirilmesi: Karaman İli Sarıveliler Örneği
}

\author{
$\odot$ Murat Demirbük ${ }^{\mathrm{a}, *}, \quad \odot$ Bekir Ayyıldız ${ }^{\mathrm{b}}$ \\ ${ }^{a}$ Tarım ve Orman İl Müdürlügü̈, Sivas, Türkiye \\ ${ }^{b}$ Bozok Üniversitesi, Ziraat Fakültesi, Tarım Ekonomisi Bölümü, Yozgat, Türkiye \\ *Sorumlu yazar/corresponding author: mdemirbuk@hotmail.com \\ Geliș/Received 09/05/2020 \\ Kabul/Accepted 20/10/2020
}

\begin{abstract}
ÖZET
Ülkeler kendi çiftçilerini çeşitli araçlarla desteklemektedir. Hibe şeklinde destekleme modeli giderek yaygınlaşmaktadır. Bu çalışmada dış kaynaklı bir kırsal kalkınma projesince desteklenen örtü altı sebze yetiştiriciliği hibe programının Sarıveliler ilçesindeki uygulaması değerlendirilmiştir. Çiftçilerden 62'si programdan yararlanmış, 62'si yararlanmamış olmak üzere toplam 124 anket yapılmıştır. Elde edilen veriler ki kare ve Mann Whitney $U$ testleri ile analiz edilmiştir. Analizler sonucu hibe programından yararlanan ve yararlanmayan çiftçiler arasında; tarımsal gelir, bilgi kaynakları ve daha önce başka bir hibe programından yararlanma yönünden istatistiksel olarak farklılık tespit edilmiştir. Ancak bu iki grup arasında çiftçilerin eğitim durumları, deneyimleri ve toplam arazi miktarları açısından bir fark görülmemiştir. Ayrıca çiftçilerin farklı kaynaklardan elde ettikleri gelir ile tarıma yatırım yapma konusunda kararsız oldukları görülmüştür. Tarımsal geliri yüksek olan çiftçiler, hibe programlarından yararlanarak yine tarıma yatırım yapmaktadır. Hibe programından yararlanmanın, bir yeniliğin kabulü ve yatırım kararını içerdiği gözden kaçırılmamalıdır. Bu nedenle programlar mutlaka kapsamlı bir yayım faaliyeti ile tanıtılmalıdır. Çiftçilerin gelirlerini artıracak etkin üretim modellerinin tanıtılması için çalışmalar yapılmalıdır. Araştırma sonucuna göre, kadınların programdan yararlanma oranı \% 17, yararlanıcıların ortalama yaşı 45 'tir. Bu durum hibe programlarından kadınların ve gençlerin daha fazla yararlanması için gerekli önlemler alınması gereğini ortaya koymaktadır.
\end{abstract}

\section{Evaluation of the Factors Affecting Benefiting from the Grant Program in Rural} Development Projects, Case Study of Sarveliler, Karaman Province

\section{ABSTRACT}

Countries support their farmers with various tools. Using grant as a tool to support farmers has been increasing recently. In this study, implementation of the grant program for greenhouse, which is one of the outsourced rural development projects, in Sariveliler district was evaluated. A survey was conducted with 124 farmers, 62 of whom benefited from the program, 62 of whom did not. The data obtained were analysed by chi square and Mann Whitney U tests. As a result of the analyses, it was seen that farmers' agricultural income, sources of information and benefiting from another grant program were statistically different. No statistically significant difference was observed in terms of the educational status of the farmers, their experiences and the farm size. In addition, it was observed that they were undecided about investing in agriculture with the income they obtained from different sources. Farmers with high agricultural income invest in agriculture again by making use of the grant schemes. It should not be ignored that benefiting from the grant program includes acceptance of an innovation and investment decision. For this reason, grant programs must be introduced with an effective extension program. Efforts should be made to introduce effective production models that will increase the income of farmers. The rate of women benefiting from the program is $17 \%$ and the average age of the beneficiaries is 45 . Necessary measures should be taken for women and young people to benefit more from the grant programs.

Anahtar Sözcükler: Kirsal kalkınma Hibe Yenilik

Keywords:

Rural development Grant Innovation

(c) OMU ANAJAS 2021 


\section{Giriş}

Tarım sektörü ve üreticiler, sanayi devriminden günümüze devletler tarafindan çeşitli politikalar ile desteklenmektedir. Ticaretin serbestleştirilmesi ve bu serbestleştirmeye tarım ürünlerinin dahil edilmesi sonucu bu desteklemeler önem kazanmıştır. Tarımın insan beslenmesindeki önemi, küresel bazda nüfus artış hızı ve gıda güvenliği açısından bakıldığında bu desteklemelerin devam etmesi hayati önem taşımaktadır.

Sanayileşmenin artması ile birlikte kırsal alanlardan kentlere göç artmış, kırsal alanlardaki nüfus azalmış ve azalmaya devam etmektedir. Yukarıda sayılan nedenlerle birlikte tarım sektörünün desteklenmesi, göçün önlenmesi, bölgeler arası gelişmişlik farklarının giderilmesi ve kırsal alanlarda yaşayan tarım üreticilerinin gelirlerinin yükseltilerek refah düzeylerinin artırılması için kırsal kalkınma projeleri önemli birer müdahale aracı olmuştur.

Türkiye'de farklı kaynaklar kullanılarak uygulanan kırsal kalkınma projelerinin yanı sıra kırsal alandaki üreticileri desteklemek amacıyla çeşitli hibe programları uygulanmaktadır. Bu programlar Kırsal Kalkınma Yatırımlarının Desteklenmesi Programında (KKYDP) olduğu gibi ulusal kaynaklar ile veya IPARD programında görülebileceği üzere uluslararası organizasyonlardan sağlanan fonlarla hayata geçirilmektedir.

KKYDP 2006 yılından itibaren çiftçilerin hibe uygulamaları yolu ile desteklenmesi modelini hayat geçiren en kapsamlı kamu müdahalesidir. KKYDP, Avrupa Birliği uyum sürecinde IPARD programından potansiyel yatırımcıların kapasitelerinin geliştirilmesi için hayata geçirilmiş olmasına karşın, IPARD programı başladıktan sonrada uygulanmaya devam etmiştir.

Son yıllarda Türkiye'de kırsal kalkınma programları ve projelerinde hibe uygulamaları giderek yaygınlaşmaktadır. Kırsal alanda yaşayan çiftçilerin gereksinim duyduğu yatırımları hayata geçirebilmesi için finansman kaynakları bulmada, krediye ulaşmakta güçlük geçtikleri bilinmektedir. Hibe programları ile sağlanan finansman, yatırımların hayata geçirilmesinde önemli bir kaynaktır. Uzun yıllar devam eden hibe uygulamaları çiftçiler için yatırım planlamasında önemli bir yer tutmaya başlamıştır. Bu süreçte hibe uygulama konusunda kamu kurumlarının kapasitelerin arttı̆̆ söylenebilir.

Yenilikçi hibe fonları son dönemlerde ortaya çıkmasına karşın geniş şekilde uygulanmaktadır ancak bu programların işlevselliği ve etkileri ile ilgili çalışmalar sınırlıdır (Ton ve ark., 2013). KKYDP'nin uygulanmasından sonra Türkiye'de hibe programının etkilerini, yararlanıcıların sosyo ekonomik özeliklerini ortaya koyan çalışmalar da artmıştır.

Bu çalışmaların bir kısmı KKYDP alt programı olan makine ekipman alımları ile (Demirbük, 2013; Çağlar, 2019) veya bireysel sulama sistemleri ile ilgilidir (Yolal, 2019). Türkiye'de uygulanan dış kaynaklı projeler ile ilgili çalışmalar da bulunmaktadır (Alnıaçık, 2015). Bu çalışmalardan hibe programının net etkisini değerlendirmeye yönelik olanlar (Çobanoğlu ve ark, 2017) bulunmakla birlikte daha çok yararlanıcıların sosyo ekonomik özellikleri ele alınmıştır (Demirbük, 2013; Alnıaçık, 2015).

Hibe programlarının amaçları arasında yeni teknolojilerin üreticiler tarafından kullanımını yaygınlaştırarak daha kaliteli ve pazar isteklerine uygun üretim yapılmasını sağlamak önemli bir hedef olarak yer almaktadır (KKYDP Tebliğ, 2013). Araştırma konusu, yüksek tünel sera yapımına yönelik bir hibe programıdır ve uygulama bölgesi için bir yeniliktir. Bu nedenle bulgular, yalnızca hibe programlarını inceleyen araştırmalar ile değil aynı zamanda çiftçilerin yeniliklere karşı tutumları ve yatırım kararlarını etkileyen çalışmalarda elde edilen sonuçlar ile de karşılaştırılmıştır.

Çiftçilerin yatırım kararları almalarını ve yeniliklere karşı tutumlarını belirlemeye yönelik çok sayıda çalışma bulunmaktadır. Çiftlik yapısının ötesinde, çiftçilerin ekonomik ve sosyo-demografik özelliklerinin yanı sıra, tarımda gelecekleri ile ilgili tutum ve perspektiflerinin de yatırım yapma kararlarını etkilemesi beklenmektedir (Lefebvre ve ark., 2014).

Yeniliklerin benimsenmesi, kişisel, sosyal, kültürel ve ekonomik faktörlerin yanı sıra yeniliğin kendi özelliklerine de bağlıdır (Pannell ve ark. 2006). Yeniliklerin benimsenmesinde etkili olan demografik, sosyo ekonomik faktörlerin yanı sıra, çiftlik yapısı ve faaliyetleri ile ilgili birden fazla faktörün değerlendirildiği çalışmalar ile birlikte (Sezgin ve ark, 2010; Howley ve ark. 2012; Melesse, 2018; Kılıçtek ve Aksoy, 2019) yalnızca tek bir faktörün yeniliklerin benimsenmesi üzerine etkisinin ele alındığı çalışmalar da bulunmaktadır (Diiro ve Sam, 2015)

Uluslararası Tarımsal Kalkınma Fonu (IFAD) tarafından sağlanan fon desteğiyle, Tarım ve Orman Bakanlı̆̆ı ve Birleşmiş Milletler Kalkınma Programı (UNDP) tarafından Konya ve Karaman'ın seçilmiş ilçelerinde, Göksu Taşeli Havzası Kalkınma Projesi (GTHKP) uygulanmaktadır.

$\mathrm{Bu}$ çalışma, Karaman İli Sarıveliler ilçesinde GTHKP tarafindan uygulanan örtü altı sebze yetiştiriciliği hibe programından yararlanan ve yararlanmayan çiftçilerin sosyo ekonomik özelliklerinin ve yatırım kararlarına ilişkin bazı tutumlarının karşılaştırılarak, hangi sosyo ekonomik özellikler ve tutumlar açısından farklılaştıklarını tespit edebilmek için yapılmıştır. Elde edilen sonuçlara dayanılarak gelecekte uygulanacak hibe programlarına dair öneriler geliştirilmiştir. 


\section{Materyal ve Yöntem}

Araştırma, Karaman İli Sarıveliler ilçe merkezi ve köylerinde ikamet edip, çiftçilik yapan aile işletmelerinde yürütülmüsstür. $\mathrm{Bu}$ işletmelerin en temel özelliği işgücü gereksinimini hane halkından sağlaması, dışarıdan bir işgücüne ihtiyaç duymamasıdır. Araştırmanın temel materyali bu bölgede yaşayan üreticiler ile yüz yüze yapılan anketlerden elde edilmiştir. Bölgede, GTHKP tarafından uygulanan örtü altı yetiştiriciliği hibe programının 2019 yılındaki desteklemelerinden yararlanan çiftçilerin tamamı ile anket yapılması planlanmış ancak, 64 yararlanıcının 2'sine ulaşılamamıştır. Ulaşılan 62 yararlanıcı ve karşılaştırma yapılabilmesi için bu çiftçiler ile aynı bölgelerde yaşayan ama desteklemeden yararlanmayan 62 çiftçi rastgele örnekleme yöntemiyle seçilerek toplamda 124 çiftçi ile yüz yüze görüşülerek anket yapılmıştır.

Anket formları iki bölümden oluşturulmuştur. İlk bölümde çiftçilerin sosyo ekonomik özelliklerine ait verileri toplamaya yönelik sorular bulunmaktadır. İkinci bölümde ise yatırım kararında etkili olabileceği düşünülen önermeler verilmiş ve çiftçilerin yatırım kararına dair tutumları ölçülmeye çalışılmıştır.

Sosyo ekonomik veriler ve önermelere verilen yanıtlar hibe programından yararlanan ve yararlanmayan her iki grup için ayrı ayrı analiz edilmiş, bu şekilde hibe programından yararlanmaya ve getirilen yeniliği kabul edip yatırım yapmaya karar vermede etkili olan faktörler tespit edilmeye çalışılmıştır. Elde edilen verilerin yorumlanması için tanımlayıcı istatistikten yararlanarak oluşturulan istatistik tablolar kullanılmıştır. Hibe programından yararlanan ve yararlanmayanların arasında istatistiksel olarak bir farklılık olup olmadığını analiz edebilmek için parametrik olmayan testlerden ki-kare ve Mann Whitney U testleri kullanılmıştır.

Analizlerde kullanılan tarımsal gelirler çiftçilerin tarımsal faaliyetlerden elde ettiği gelirleri ifade etmektedir. Tarımsal gelir hesaplanırken, çiftçilerin beyanları alınmış ancak analizlere başlamadan önce bu beyanlar Karaman İl Tarım ve Orman Müdürlüğü tarafından hazırlanan ve resmi hesaplamalarda kullanılan ürün maliyet cetvelleri ile karşılaştırılmıştır. Yapılan karşılaştırma ile çiftçilerin işlediği arazi miktarı, niteliği ve elde ettiği ürüne göre gerekli düzeltmeler yapılarak analizlerde kullanılan tarımsal gelirler elde edilmiştir.

\section{Bulgular ve Tartışma}

Çalışma kapsamındaki çiftçilerin ilk olarak sosyo ekonomik özellikleri ele alınmış ve bilgiler tablolar halinde verilmiştir. Çizelge 1'de çiftçilerin cinsiyetlerine göre dağılımları görülmektedir.

Çalışma bölgesinde uygulanan hibe programından yaralanan kadınların oranı \% 17.7'dir. Denizli ilinde yapılan çalışmada, Tarım ve Kırsal Kalkınmayı Destekleme Kurumunun (TKDK) aracılık ettiği IPARD desteklerinden yararlanan kadın çiftçilerin oranı \% 9.8 olarak bulunmuştur (Akkoyun, 2018). Toplumsal cinsiyet eşitliği açısından istenilen hedefe ulaşılamamış olsa da bölgede hibe programından yararlanan kadınların oranı Denizli ilinde yapılan çalışmada bulunan oranın neredeyse iki katıdır. Bu farkın oluşmasında, başvuru değerlendirme aşamasında kadınlara, erkek çiftçilerden daha fazla puan verilmesi olduğu kadar, örtü altı yetiştiricilik konusunda kadınların tecrübesinin de önemli olduğu düşünülmektedir. Araştırma bölgesi örtü altı yetiştiriciliğin yaygın olduğu Alanya ilçesine yakındır ve özellikle kış aylarında aileleri ile birlikte ortakçılık yapmak üzere Alanya'ya giden kadınlar oradaki seralarda çalışarak önemli tecrübeler kazanmışlardır.

Etiyopya'da yapılan çalışmada hane reisinin kadın olduğu aile işletmelerinde, bu durumun yeniliklerin uygulanmasında negatif bir etkiye sahip olduğu sonucuna varılmıştır. Gerekçe olarak erkeklerin hareket alanlarının daha geniş olması ve çeşitli eğitim ve toplantılara daha çok katılma olanaklarının bulunması gösterilmiştir (Melesse, 2018). Erkeklerin yatırım sermayesine kadınlara oranla erişiminin çok daha fazla olması bu anlamda erkeklerin ön plan çıkmasının nedeni olabilir (Nbiwo ve Alimba, 2013).

Çizelge 1. Çiftçilerin cinsiyetlerine göre dağılımları

Table 1. Distribution of farmers by gender

\begin{tabular}{lccccccc}
\hline Hibeden yararlandım & & \multicolumn{2}{c}{ Evet } & \multicolumn{2}{c}{ Hayır } & \multicolumn{2}{c}{ Toplam } \\
\cline { 3 - 8 } & & Say1 & $\%$ & Say1 & $\%$ & Say1 & $\%$ \\
\hline Cinsiyet & Kadın & 11 & 17.7 & 7 & 11.3 & 18 & 14.5 \\
\cline { 2 - 8 } & Erkek & 51 & 82.3 & 55 & 88.7 & 106 & 85.5 \\
\hline
\end{tabular}

Çizelge 2'de görüleceği gibi hibe programından yararlananların yaş ortalamaları 45,41 ve ortalama deneyimleri ise 21,79 yıldır. Denizli'de yapılan çalışmada hibe programından yararlananların $\% 63.4$ 'ü 48 ve üzeri yaştadır ve $\%$ 48.8‘i 23 yll ve daha az deneyime sahiptir. \% 51.2'si ise 24 yıl ve üzeri deneyime sahiptir (Akkoyun, 2018). Trabzon da IPARD arıcılık hibeleri ile ilgili yapılan çalışma sonuçlarına göre hibe alanların \% 62.5’i 41-60 yaş arasındadır (Keleş, 2018). Sivas Erzincan Kalkınma Projesinde ise alet makine hibe programından yararlananların \% 39.7'si 40-49 yaş arasındadır (Alnıaçık, 2015). Nwibo ve Alimba (2013) Nijerya'da yaptıkları çalışmada tarım 
işletmelerinde 40-59 yaş aralığının yatırım konusunda daha aktif olduğunu tespit etmişlerdir. Lefebvre ve arkadaşları (2014) ise çalışmalarında 40 yaş altındaki çiftçilerin 60 yaş üzerine oranla yatırım yapmaya daha fazla istekli olduklarını ancak farkın istatistiksel olarak önemli olmadı̆̆ını belirtmişlerdir.

Araştırmada tespit edilen ortalama yaş ve deneyim tarımsal üretim açısından sürekliliği sağlayabilecek ve verimli denilebilecek bir dönemdir. Aile işletmelerinde yeniliklerin uygulanmasını konu alan farklı çalışmalarda birbiri ile çelişkili sonuçlara ulaşılmıştır.

Bazı çalışmalarda yaşın olumlu, bazılarında ise olumsuz etkileri olduğu tespit edilmiştir (Melesse, 2018). Gençlerin, yaşlılara oranla yenilikleri daha kolay kabul edebilecekleri, yaşlıların bu konuda daha tutucu davranabilecekleri varsayılabilir (Howley ve ark., 2012). Nwibo ve Alimba (2013) ise deneyim faktörünü yatırım kararının ana belirleyicilerinden biri olarak işaret etmişlerdir.

Araştırma alanındaki çiftçilerin İşledikleri toplam arazi miktarlarının ortalaması 21.19 dekardır. Melesse (2018), yaptı̆̆ çalışmada çiftçilerin farklı ürünler yetiştirebileceği büyüklükte araziye sahip olmaları veya karma üretim yapmaları durumunda toplam arazi varlığının yeniliklere adapte olma konusunda pozitif bir etkiye sahip olduğunu belirtmektedir.

Toplam arazi varlığı araştırma bölgesinin Torosların yükseklerinde yer almasından kaynaklı olarak fazla değildir. Tarımsal gelir ve toplam gelir ortalamaları sırasıyla 24580.64 ve 32419.35 TL'dir. Hibe programından yararlanmamış çiftçilerin ise yaş ortalamaları 45.98, deneyimleri 24.30 yıl ve işledikleri ortalama arazi 19.79 dekardır.

Çizelge 2. Çiftçilere ait bazı sosyo-ekonomik göstergeler

Table 2. Some socio-economic indicators of farmers

\begin{tabular}{lcccccc}
\hline \multicolumn{2}{c}{ GTHKP Hibe desteği } & Yaş & $\begin{array}{c}\text { Deneyim } \\
(\text { Yıl })\end{array}$ & $\begin{array}{c}\text { Ortalama arazi } \\
(\mathrm{da})\end{array}$ & $\begin{array}{c}\text { Tarımsal gelir } \\
(\mathrm{TL})\end{array}$ & $\begin{array}{c}\text { Toplam gelir } \\
\text { (TL) }\end{array}$ \\
\hline \multirow{2}{*}{ Evet } & Ortalama & 45.41 & 21.79 & 21.19 & 24580.64 & 32419.35 \\
& Standart Sapma & 10.30 & 11.22 & 16.09 & 12940.65 & 18310.21 \\
\multirow{2}{*}{ Hayır } & Ortalama & 45.98 & 24.30 & 19.79 & 17846.77 & 31841.93 \\
& Standart Sapma & 11.16 & 13.72 & 15.48 & 10867.90 & 17392.66 \\
\multirow{2}{*}{ Toplam } & Ortalama & 45.70 & 23.04 & 20.49 & 21213.70 & 32130.64 \\
& Standart Sapma & 10.70 & 12.54 & 15.74 & 12371.48 & 17786.95 \\
\hline
\end{tabular}

Çizelge 2'de verilen ortalamaların istatistiksel olarak anlamlı olup olmadıklarını görebilmek için Mann-Whitney U testi yapılmış ve sonuçlar Çizelge 3 'te gösterilmiştir. Analiz sonucu hibe programından yaralanan ve yararlanmayan çiftçilerin yaş, deneyim, toplam arazi varlığı ve toplam gelirlerine ait verilere bakıldığında $p$ değerlerinin 0.05 'ten büyük oldukları görülmektedir.

Bu sonuç iki grup arasında istatistiksel olarak \% 5 önem seviyesine göre bir farklılık olmadığını göstermektedir. Yeniliklerin kabul edilmesine ilişkin Erzurum'da yapılan çalışmada yaş faktörü yeniliğin benimsenmesinde istatistiksel olarak anlamlı bulunmuştur. Gençlerin yeniliği benimsemede öne çıktığı görülmüştür (Sezgin ve ark., 2010).

Olsen ve Lund (2009) Tarımda yatırım davranışlarını etkileyen teşvikler ve sosyoekonomik faktörler adlı çalışmalarında genç çiftçilerin yaşlılara göre yatırım yapmalarının daha olası olduğunu, yatırım eğiliminin aynı zamanda deneyim ile de ilgili olduğunu vurgulamıştır. Programdan yararlananların, 20 yılın üzerinde deneyimleri olduğu görülmektedir. Bu durum yukarıdaki tespit ile uyumlu görünmektedir.

Tarımsal gelire ait $\mathrm{p}$ değeri 0.05 'ten küçük olup 0.001'dir. Hibe programından yararlananlar ile yararlanmayanların tarımsal gelirleri arasındaki fark istatistiksel olarak anlamlıdır ve Bursa ilinde yapılan çalışma ile paralellik göstermektedir. Bursa ilinde yapılan çalışmada tarımsal işletmelerin, hibe desteğinden yararlanma durumu üzerine, tarımsal gelir $(p<0,10)$ ve işletme ölçeği $(p<0,10)$ değişkenlerinin etkisinin istatiksel olarak önemli olduğu belirlenmiştir (Çobanoğlu ve ark., 2017).

$\mathrm{Bu}$ sonuç, tarımsal girişimcilerin yatırım kararında, yıllık gelirin önemli bir etkiye sahip olduğunu ortaya koymuş olan Nijerya'daki çalışma ile de paralellik göstermektedir (Nwibo ve Alimba, 2013). 
Çizelge 3. Mann-Whitney U test tablosu

Table 3. Mann-Whitney U test chart

\begin{tabular}{|c|c|c|c|c|c|c|c|c|}
\hline & \multirow{2}{*}{$\begin{array}{c}\text { GTHKP } \\
\text { hibe desteği }\end{array}$} & \multirow{2}{*}{$\mathrm{N}$} & \multicolumn{2}{|c|}{ Sira sayıları } & \multirow{2}{*}{$\begin{array}{c}\text { Mann- } \\
\text { Whitney U }\end{array}$} & \multirow{2}{*}{$\begin{array}{c}\text { Wilcoxon } \\
\text { W }\end{array}$} & \multirow{2}{*}{ Z } & \multirow{2}{*}{$\mathrm{p}$} \\
\hline & & & Ortalama & Toplam & & & & \\
\hline \multirow{2}{*}{ Yaş } & Evet & 62 & 61.44 & 3809.00 & \multirow{2}{*}{1856.000} & \multirow{2}{*}{3809.000} & \multirow{2}{*}{-.330} & \multirow{2}{*}{.741} \\
\hline & Hayır & 62 & 63.56 & 3941.00 & & & & \\
\hline \multirow{2}{*}{ Deneyim } & Evet & 62 & 59.22 & 3671.50 & \multirow{2}{*}{1718.500} & \multirow{2}{*}{3671.500} & \multirow{2}{*}{-1.020} & \multirow{2}{*}{.308} \\
\hline & Hayır & 62 & 65.78 & 4078.50 & & & & \\
\hline \multirow{2}{*}{$\begin{array}{l}\text { Toplam } \\
\text { arazi (da) }\end{array}$} & Evet & 62 & 63.75 & 3952.50 & \multirow{2}{*}{1844.500} & \multirow{2}{*}{3797.500} & \multirow{2}{*}{-.388} & \multirow{2}{*}{.698} \\
\hline & Hayır & 62 & 61.25 & 3797.50 & & & & \\
\hline \multirow{2}{*}{$\begin{array}{c}\text { Tarımsal } \\
\text { gelir (TL) }\end{array}$} & Evet & 62 & 73.01 & 4526.50 & \multirow{2}{*}{1270.500} & \multirow{2}{*}{3223.500} & \multirow{2}{*}{-3.264} & \multirow{2}{*}{.001} \\
\hline & Hayır & 62 & 51.99 & 3223.50 & & & & \\
\hline \multirow{2}{*}{$\begin{array}{l}\text { Toplam gelir } \\
\text { (TL) }\end{array}$} & Evet & 62 & 62.01 & 3844.50 & \multirow{2}{*}{1891.500} & \multirow{2}{*}{3844.500} & \multirow{2}{*}{-.153} & \multirow{2}{*}{.879} \\
\hline & Hayır & 62 & 62.99 & 3905.50 & & & & \\
\hline
\end{tabular}

Çalışma kapsamındaki çiftçilerin, eğitim durumları Çizelge 4'te verilmiştir. Programdan yaralananlar içinde ilköğretim mezunları \% 66.1 ile yararlanmayanlardan fazladır. Orta öğretim, lise ve yükseköğretim mezunu olanlar ise yararlanmayanlar arasında daha fazladır. Ancak bu oranların istatistiksel olarak anlamlı olup olmadığına bakıldığında, p değerinin 0.05 'ten büyük olduğu görülmektedir. P değeri 0.464 çıkmıştır. Bu durumda hibe programından yararlanmanın eğitim düzeyinden bağımsız olduğu kabul edilir. Başka bir deyişle hibe programından yararlanma ile eğitim düzeyi arasında bir ilişki yoktur.

Eğitim seviyesinin artması ile birlikte yeniliklerin daha hızlı kabul edilmesi beklenmektedir (Melesse, 2018). Altı Avrupa ülkesini kapsayan çalışmada, çiftçilerin \% 72'sinin ilk ve ortaöğrenim gördükleri, ortaöğretim sonrası ve yükseköğretime sahip çiftçilerin yatırım yapma niyetlerinin daha yüksek olduğu ve yatırım yapmak isteyen çiftçilerin ve diğerlerinin eğitim düzeylerinde önemli farkl1lıklar olduğu belirlenmiştir (Lefebvre ve ark, 2014).

Süt işletmelerinde yeniliklerin benimsenmesi ile ilgili Erzurum'da farklı tarihlerde yapılan iki ayrı çalışmada, öğrenim durumu ile yeniliklerin benimsenmesi arasındaki ilişki açısından iki farklı sonuca ulaşılmıştır. Birinde ilişki önemli bulunmamışken (Kılıçtek ve Aksoy, 2019) bir başka çalışmada eğitim seviyesi daha yüksek olanların yeniliklere daha kolay adapte oldukları ve yaş faktörünün istatistiksel açıdan önemli olduğu görülmüştür (Sezgin ve ark., 2010).

Başka bir çalışmada yatırım yapma konusunda, eğitim durumu \% 1 seviyesinde pozitif ve anlamlı bulunmuştur. Yazar tarafından bu durum eğitimli bireyin, yatıımın ayrıntılarını bilebileceği ve bu nedenle yatırım yapılacak alanı seçme konusunda daha iyi potansiyele sahip olabileceği şeklinde yorumlanmıştır (Nwibo ve Alimba, 2013). Yozgat ilinde yapılan çalışmada basınçlı sulama sistemleri ile ilgili hibe programından yararlananların \% 60'ının ilkokul, \% 20’sinin ortaokul, \%18’inin lise, \% 2’sinin üniversite mezunu olduğu görülmüştür (Yolal, 2019).

Yozgat ilindeki verilerden ilköğretim ve ortaöğretim yüzdeleri çalışmada elde edilen sonuçlara yakındır. Trabzon ilinde yapılan çalışmada, IPARD arıcılık hibe programından yararlananlardan ilköğretim mezunu olanlar \% 25, ortaokul mezunları \% 30, yüksek öğretim mezunları \% 17.5 bulunmuştur (Keleş, 2018). Bu çalışmada elde edilen oranlardaki farklılığın hibe konusuyla ilişkili olabileceği düşünülmektedir.

Demirbük ve Kızılaslan (2020) tarafindan Islah Amaçlı Yetiştirici Birlikleri ile Üyeleri Arasındaki İlişkilerin Analizi adıyla Sivas'ta yapılan çalışmada arıcılık yapanlar içerisinde üniversite mezunlarının oranı \% 16.8 ile diğer üreticilerden daha fazla bulunmuştur ve Trabzon ilindeki çalışma ile uygunluk göstermektedir.

Denizli ilinde yapılan çalışmada ise hibe programından yararlananların \% 31.7'si ilköğretim ve altı, \% 56.1'i lise ve \% 12.2'si yüksek öğretim mezunudur (Akkoyun, 2018). Alnıaçık (2015) tarafından Sivas'ta yapılan çalışmada tarım alet ve makinaları hibe programından yararlananların \% 65.1'i ilkokul, \% 14.3'ü ortaokul, \% 19'u lise ve \% 1,6'sı üniversite mezunudur. Sivas'taki çalışmada verilen ilkokul mezunlarının oranı da bu çalışmada hibe programından yararlanan ilköğretim mezunlarının oranına oldukça yakındır. 
Çizelge 4. Eğitim durumu

Table 4. Educational status

\begin{tabular}{|c|c|c|c|c|}
\hline \multirow{2}{*}{ Eğitim Durumu } & & \multicolumn{2}{|c|}{ Hibeden yararlandım } & \multirow[t]{2}{*}{ Toplam } \\
\hline & & Evet & Hayır & \\
\hline \multirow{3}{*}{ İlk- } & Say1 & 41 & 33 & 74 \\
\hline & Grup içinde \% & 66.1 & $53.2 !$ & \\
\hline & Toplam içinde \% & 33.1 & $26.6 !$ & \\
\hline \multirow[t]{3}{*}{ Orta- } & Sayı & 12 & 14 & 26 \\
\hline & Grup içinde \% & 19.4 & $22.6 !$ & \\
\hline & Toplam içinde \% & 9.7 & 11.3 & \\
\hline \multirow[t]{3}{*}{ Lise } & Sayı & 5 & 9 & 14 \\
\hline & Grup içinde \% & 8.1 & 14.5 & \\
\hline & Toplam içinde \% & 4.0 & 7.3 & \\
\hline \multirow[t]{3}{*}{ Yüksek } & Sayı & 4 & 6 & 10 \\
\hline & Grup içinde \% & 6.5 & $9.7 i$ & \\
\hline & Toplam içinde \% & 3.2 & $4.8^{i}$ & \\
\hline$x^{2}=2.562$ & $\mathrm{SD}=3 \quad \mathrm{p}$ & .464 & & \\
\hline
\end{tabular}

Çiftçilerin sosyo ekonomik özellikleri ile destekten yararlanma arasında bir bağıntı olup olmadığını görebilmek için çapraz tablo oluşturularak uygun olan verilere ki kare analizi yapılmıştır.

Çizelge 5'te hibe programından yararlananlar ile yararlanmayanların bilgi kaynakları açısından farklılık olup olmadığı karşılaştırılmıştır. Program ile ilgili bilgiyi, İlçe Müdürlüğünden alanların oranı yararlanıcılar için \% 57.7 diğerleri için \% 42.3'tür. Hibe programını danışmanlardan öğrenenlerin oranı genel toplam içinde oldukça düşüktür (\% 3.2). Ki kare testi sonucu p değerinin 0.05 ’ten küçük olduğu görülmektedir (0.040). Çiftçilerin bilgi kaynakları arasındaki istatistiksel olarak \% 5 önem seviyesine göre anlamlı bir bağlantı olduğu görülmüştür. Hibe programını yürüten İl/İlçe Tarım ve Orman Müdürlüklerinden alınan bilgiler ile doğru yönlendirilmenin bu farklılığın ortaya çıkmasında etkili olduğu söylenebilir.

Yozgat'ta yapılan çalışmada hibe destek programını üreticilerin \% 40’1 Tarım ve Orman Müdürlükleri, \% 34'ü TV, \% 16'sı diğer çiftçiler, \% 10'u danışman aracilığıyla öğrendiklerini söylemişlerdir (Yolal, 2019). Trabzon'daki çalışmada hibeden yararlananların \% 92.5'i danışmanla (yayım elemanları) hiç görüşmediklerini belirtmiştir (Keleş, 2018). Sivas'ta yürütülen çalışmada, bilgi kaynakları ile ilgili soruya araştırmaya katılanların \% 26.09'u hibe programını İl/ilçe müdürlüklerinden, \% 40.58'i arkadaşından öğrendiğini belirtmiştir (Alnıaçık, 2015). Çiftçilerin bilgi kaynakları arasında, danışmanların çok düşük bir düzeyde olduğu görülmektedir.

Çizelge 5. Çiftçilerin hibe programı konusunda bilgi kaynakları

Table 5. Information sources of farmers about the grant support program

\begin{tabular}{ccrrr}
\hline \multicolumn{2}{c}{ Bilgi kaynağı } & \multicolumn{2}{c}{ Hibeden yararlandım } & \multirow{2}{*}{ Toplam } \\
& & Evet & Hayır & \\
\hline \multirow{2}{*}{ İlçe } & Sayı & 45 & 33 & 78 \\
Müdürlüğü & Grup içinde \% & 57.7 & 42.3 & 100.0 \\
& Toplam içinde \% & 72.6 & 53.2 & 62.9 \\
& Sayı & 2 & 8 & 10 \\
Danışman & Grup içinde \% & 20.0 & 80.0 & 100.0 \\
& Toplam içinde \% & 3.2 & 12.9 & 8.1 \\
Çevre, diğer & Sayı & 15 & 21 & 36 \\
çiftçiler & Grup içinde \% & 41.7 & 58.3 & 100.0 \\
& Toplam içinde \% & 24.2 & 33.9 & 29.0 \\
$\mathrm{x}^{2}=6.446$ & & SD $=2$ & & $\mathrm{p}=0.040$ \\
\hline
\end{tabular}


Çalışma kapsamındaki çiftçilere hibe programını yürüten İlçe Müdürlüğüne uğrama sıklıkları sorulmuştur ve alınan yanıtlar Çizelge 6'da özetlenmiştir. Ayda 1-2 kez uğradığını söyleyenlerin içinde programdan yararlananlar $\%$ 53.6'dır. 3 ayda 1-2 kez ve 6 ayda 1-2 kez uğradıklarını söyleyenler içerisinde de programdan yararlananların oranı \% 50'nin üzerinde ve yararlanmayanlardan yüksektir. Yılda 1-2 kez uğrayanlar içerisinde ise programdan yararlanmayanlar \% 70 ile oldukça yüksektir. Bu farka rağmen, programdan yararlanan ve yararlanmayanların İlçe Müdürlüğüne uğrama sıklıkları arasında istatistiksel olarak \% 5 önem seviyesine göre bir bağlantı bulunamamıştır. Ki kare analizine ait $\mathrm{p}$ değeri Çizelge 6'da görülebileceği gibi 0.280 bulunmuştur.

Çizelge 6. İlçe müdürlüğüne uğrama sıklığ

Table 6. Frequency of visiting the district directorate

\begin{tabular}{|c|c|c|c|c|}
\hline & & \multicolumn{2}{|c|}{ Iibeden yararlandım } & Toplam \\
\hline \multicolumn{2}{|c|}{ İlçe müdürlüğünü ziyaret } & Evet & Hayır & \\
\hline & Say1 & 30 & 26 & 56 \\
\hline \multirow[t]{3}{*}{ Ayda 1-2 kez } & Grup içinde \% & 53.6 & 46.4 & 100.0 \\
\hline & Toplam içinde \% & 24.2 & 21.0 & 45.2 \\
\hline & Sayı & 17 & 14 & 31 \\
\hline \multirow[t]{3}{*}{3 Ayda 1-2 kez } & Grup içinde \% & 54.8 & 45.2 & 100.0 \\
\hline & Toplam içinde \% & 13.7 & 11.3 & 25.0 \\
\hline & Sayı & 9 & 8 & 17 \\
\hline \multirow[t]{2}{*}{6 Ayda 1-2 kez } & Grup içinde \% & 52.9 & 47.1 & 100.0 \\
\hline & Toplam içinde \% & 7.3 & 6.5 & 13.7 \\
\hline \multirow[t]{3}{*}{ Y1lda 1-2 kez } & Sayı & 6 & 14 & 20 \\
\hline & Grup içinde \% & 30.0 & 70.0 & 100.0 \\
\hline & Toplam içinde \% & 4.8 & 11.3 & 16.1 \\
\hline$x^{2}=3.835$ & $\mathrm{SD}=$ & & & $\mathrm{p}=0.280$ \\
\hline
\end{tabular}

Çalışma kapsamındaki çiftçilere daha önce başka bir hibe programından yararlanıp yararlanmadıkları sorulmuş ve sonuçlar Çizelge 7'de verilmiştir. Tüm çiftçiler içerisinde daha önce başka bir hibe programından yararlananların oranı \% 23.4'dür. Bunların içerisinde ise GTHKP kapsamındaki hibe programından yararlananların oranı \% 69 gibi büyük bir çoğunluğu oluşturmaktadır. Tüm çiftçilerin \% 76.6's1 ise daha önce hiçbir hibe programından yararlanmadıklarını bildirmiştir.

Ki kare analizi soncunda $\mathrm{p}$ değeri 0.020 bulunmuştur ve bu değer 0.05 'ten küçük olduğu için daha önce hibe desteğinden yararlanma ile GTHKP kapsamındaki hibe desteğinden yararlanma arasında \% 5 önem seviyesine göre istatistiksel olarak bir bağlantı olduğu görülmüştür. Bu bağlantının beklenen bir sonuç olduğu söylenebilir. Daha önce hibe programına başvurup yararlananların, edindikleri tecrübe ile sonraki hibe programlarına başvuru yapma olasıkları yüksektir. Bu ilişki, bir hibe programından yararlanmanın, tekrar yararlanma eğilimini artırdığını işaret etmektedir. $\mathrm{Bu}$ sonuç, üreticilerin bir destek programından ilk yararlanmalarında motive edilmelerinin oldukça önemli olduğunu ortaya koymaktadır.

Çizelge 7. Daha önce başka bir hibe programından yararlanma durumu

Table 7. Previously benefiting from another grant program

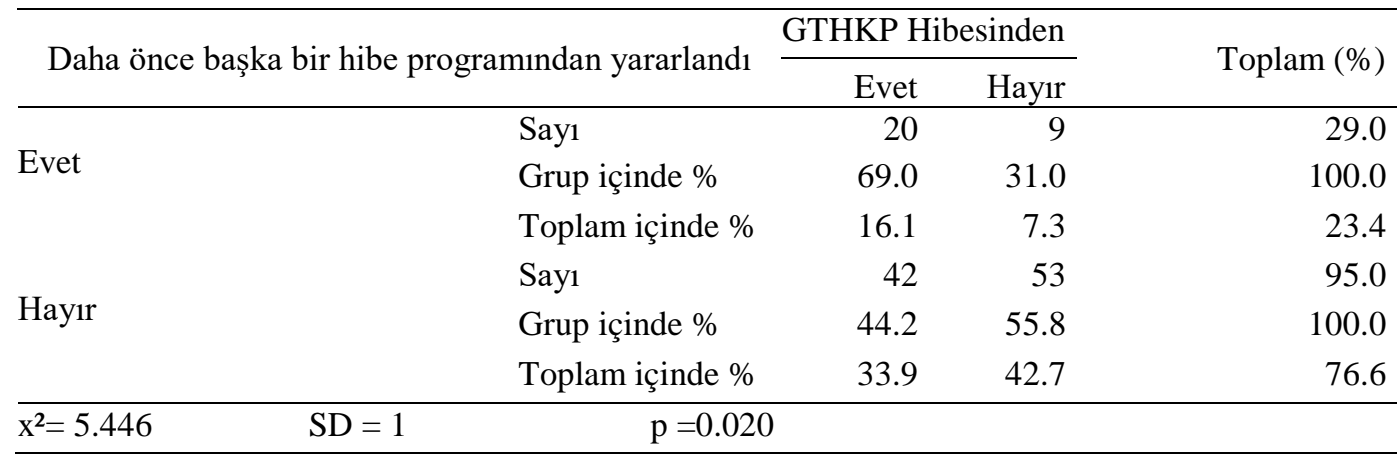


Çiftçilerin hibe programlarına karşı tutumlarını ölçebilmek için 5'li likert tipi 10 adet önerme sunulmuş ve yanıtları alınmıştır. Çizelge 8'de görülebileceği gibi her bir önerme için hibe programından yararlananlar ve yararlanmayanların verdikleri yanıtların ortalaması ve standart sapmaları ayrı ayrı verilmiştir. Ortalamaların yorumlanmasında Palaz ve Boz (2008) tarafindan geliştirilen aşağıdaki yorumlama skalası kullanılmıştır: Ortalama 1.00-1.49 aras1 $=$ Kesinlikle Katılmiyorum $(\mathrm{KKtm}), 1.50-2.49$ aras1 = Kat1lmiyorum $(\mathrm{Ktm}), 2.50-3.49$ aras1 $=$ Kararsızım (Krz), 3.50-4.49 aras1 = Kat1liyorum $(\mathrm{K})$ ve 4.50-5.00 aras1 = Kesinlikle Kat1liyorum (KK). Bu skalaya göre, çiftçiler, araştırmada yer verilen 10 önermeden, 1'inde kararsız, 6'sına katılmakta ve 2'sine kesinlikle katılmaktadır. Ortalamalar arasında Kesinlikle Katılmıyorum ve Katılmıyorum kategorilerinde herhangi bir önerme bulunmamaktadır. Önermelerin ilk dokuzunda hibe programından yararlananlar ve yararlanmayanlar aynı kategoride yer alırken 10 numaralı önermede programdan yararlananlar 'Katıliyorum' kategorisinde, programdan yararlanmayan çiftçiler ise 'Kesinlikle katılıyorum' kategorisinde yer almıştır. Çiftçiler sahip oldukları farklı gelir kaynakları olması durumunda bu gelir kaynaklarından tarımsal üretim için yatırım yapma konusunda kararsız oldukları görülmektedir.

Çizelge 8. Çiftçilerin önermelere katılım durumu

Table 8. Farmers' participation in propositions

\begin{tabular}{|c|c|c|c|c|c|}
\hline \multicolumn{2}{|c|}{ Önerme } & Yararlandım & Ortalama & Standart & Katılma \\
\hline \multirow{2}{*}{1} & \multirow{2}{*}{ Katkı payı ödemekte zorlanıyorum } & Evet & 4.0323 & .95739 & $\mathrm{~K}$ \\
\hline & & Hayır & 4.2419 & .80338 & K \\
\hline \multirow{2}{*}{2} & \multirow{2}{*}{$\begin{array}{l}\text { Genel ekonomik durum yatırım } \\
\text { kararımda etkilidir }\end{array}$} & Evet & 4.2097 & .57651 & K \\
\hline & & Hayır & 4.3710 & .65871 & K \\
\hline \multirow{2}{*}{3} & \multirow{2}{*}{$\begin{array}{l}\text { Krediye ulaşabilmek yatırım kararımda } \\
\text { etkilidir }\end{array}$} & Evet & 3.8387 & .89064 & K \\
\hline & & Hayır & 4.0645 & .80716 & K \\
\hline \multirow{2}{*}{4} & \multirow{2}{*}{$\begin{array}{l}\text { Çevrem yatırım yapmam konusunda } \\
\text { beni teşvik ediyor }\end{array}$} & Evet & 3.9355 & .72136 & K \\
\hline & & Hayır & 3.7419 & .84805 & $\mathrm{~K}$ \\
\hline \multirow{2}{*}{5} & \multirow{2}{*}{$\begin{array}{l}\text { Farklı gelir kaynaklarımdan tarıma } \\
\text { yatırım yapıyorum }\end{array}$} & Evet & 3.2419 & 1.2238 & Krz \\
\hline & & Hayır & 3.4516 & 1.0191 & Krz \\
\hline \multirow{2}{*}{6} & \multirow{2}{*}{$\begin{array}{c}\text { Pazarlama olanakları yatırım kararında } \\
\text { etkilidir }\end{array}$} & Evet & 4.2742 & .44975 & $\mathrm{~K}$ \\
\hline & & Hayır & 4.3548 & .57536 & K \\
\hline \multirow{2}{*}{7} & \multirow{2}{*}{$\begin{array}{l}\text { Yatırım sonrası elde etmeyi beklediğim } \\
\text { gelir yatırım kararında etkilidir }\end{array}$} & Evet & 4.1452 & .47380 & K \\
\hline & & Hayır & 4.3387 & .47713 & $\mathrm{~K}$ \\
\hline \multirow{2}{*}{8} & \multirow{2}{*}{$\begin{array}{c}\text { Önceki olumlu uygulamalar yatırım } \\
\text { kararımda etkilidir }\end{array}$} & Evet & 4.5323 & .50303 & KK \\
\hline & & Hayır & 4.5000 & .53562 & KK \\
\hline \multirow{2}{*}{9} & \multirow{2}{*}{$\begin{array}{c}\text { Uygun arazi bulunması yatırım } \\
\text { kararımda etkilidir }\end{array}$} & Evet & 4.2258 & 42153 & $\mathrm{~K}$ \\
\hline & & Hayır & 4.4194 & 49748 & $\mathrm{~K}$ \\
\hline \multirow{2}{*}{10} & \multirow{2}{*}{$\begin{array}{c}\text { Uygun altyapının bulunması yatırım } \\
\text { kararımda etkilidir }\end{array}$} & Evet & 4.4194 & 49748 & $\mathrm{~K}$ \\
\hline & & Hayır & 4.5161 & .50382 & KK \\
\hline
\end{tabular}

Çiftçilerin önermelere verdiği yanıtların ortalamaları arsındaki farkların istatistiksel olarak anlamlı olup olmadıklarını görebilmek için Mann Whitney U testi yapılarak sonuçları Çizelge 9'da verilmiştir. Yatırım sonrası gelir beklentim yatırım kararımda etkilidir ve Uygun arazi bulunması yatırım kararımda etkilidir önermelerinin $p$ değerleri 0.05 'ten küçük çıkmıştır.

Bu iki önerme \% 5 önem düzeyinde istatistiksel olarak anlamlıdır. Ortalama rank değerlerine bakıldığında hibe programından yararlanmayanların değerleri yararlananlardan daha yüksektir. Erzurum'da hayvancılık işletmelerinde yeniliğin benimsenme düzeyinin tespit edilmesi için yapılan çalışmada, yatırımın gelirde bir değişim meydana getirmesi istatistiksel olarak önemli bulunmuştur (Kılıçtek ve Aksoy, 2019).

Dolayısıyla beklenen gelir miktarı ve uygun arazinin bulunması konusunda, yararlanmayanların çok daha temkinli hareket ettiklerini söylemek olasıdır. Buna göre, destekten yararlanmayan üreticilerin yatırım sonrası gelirin yatırıma değmeyecek bir ölçekte olacağı düşüncesinden ve uygun arazileri olmamasından olumsuz yönde etkilendikleri söylenebilir. Diğer yandan programdan yararlananların beklenen gelir konusunda daha iyimser tutum alarak daha girişimci davrandıkları, aynı şekilde mevcut arazilerini yatırıma uygun hale getirmek için de daha cesur 
davrandıklarını söylemek olasıdır. Diğer 8 önerme için \% 5 önem seviyesinde istatistiksel olarak bir farklılık bulunmamaktadir.

Çizelge 9. Önermelere ilişkin Mann Whitney U testi

Table 9. Mann Whitney $U$ test on propositions

\begin{tabular}{cccccc}
\hline \multirow{2}{*}{ Önermeler } & Hibe & & \multicolumn{2}{c}{ Sıra sayıları } & p \\
& Durumu & $N$ & Ortalama & Toplam & \\
\hline \multirow{2}{*}{ Katkı payı ödemekte zorlanıyorum } & Evet & 62 & 59.02 & 3659.50 & .243 \\
& Hayır & 62 & 65.98 & 4090.50 & .243 \\
Genel ekonomik durum yatırım kararımda etkilidir & Evet & 62 & 57.80 & 3583.50 & .102 \\
& Hayır & 62 & 67.20 & 4166.50 & \\
Krediye ulaşabilmek yatırım kararımda etkilidir & Evet & 62 & 58.23 & 3610.00 & .128 \\
& Hayır & 62 & 66.77 & 4140.00 & \\
Çevrem yatırım yapmam konusunda beni teşvik ediyor & Evet & 62 & 65.94 & 4088.50 & .244 \\
& Hayır & 62 & 59.06 & 3661.50 & \\
Farklı gelir kaynaklarımdan tarıma yatırım yapıyorum & Evet & 62 & 59.50 & 3689.00 & .329 \\
& Hayır & 62 & 65.50 & 4061.00 & \\
Pazarlama olanakları yatırım kararında etkilidir & Evet & 62 & 59.36 & 3680.50 & .237 \\
Yatırım sonrası elde etmeyi beklediğim gelir yatırım & Hayır & 62 & 65.64 & 4069.50 & \\
kararında etkilidir & Evet & 62 & 57.01 & 3534.50 & .031 \\
& Hayır & 62 & 67.99 & 4215.50 & \\
Önceki olumlu uygulamalar yatırım kararımda etkilidir & Evet & 62 & 63.23 & 3920.50 & .793 \\
& Hayır & 62 & 61.77 & 3829.50 & \\
Uygun arazi bulunması yatırım kararımda etkilidir & Evet & 62 & 56.50 & 3503.00 & .022 \\
& Hayır & 62 & 68.50 & 4247.00 & \\
Uygun altyapının bulunması yatırım kararımda & Evet & 62 & 59.50 & 3689.00 & .282 \\
etkilidir (Sulama vb.) & Hayır & 62 & 65.50 & 4061.00 & \\
\hline
\end{tabular}

\section{Sonuç ve Öneriler}

Hibe uygulamasının bir finansman aracı olarak özellikle kırsal kalkınma proje ve programlarında giderek yaygınlaşacağını beklemek yanlış olmaz. Uygulamanın etkinliğini artırmak için önceki uygulamalardan çıkarılacak dersler önemlidir.

Kadınların, bilgi sahibi oldukları alanlarda hibe programına başvuru ve yatırım yapma konusunda cesur davrandıkları söylenebilir. Kadınlar ile birlikte kırsal alanda gençlerin desteklenmesi göçün önlenebilmesi ve istihdam açısından önemlidir. Programlar mutlaka, değerlendirme ve uygulama aşamalarında kadınlar ve gençler için daha yüksek puan ve hibe oranı gibi pozitif ayrımcılık unsurları içermelidir.

Tarımsal geliri yüksek olanların hibelerden yararlanma konusunda öne çıktıkları istatistiksel olarak görülmüştür. Ancak bölgesel farklılıkların azaltılmasını, daha yoksul olanların desteklenmesini hedefleyen kırsal kalkınma projelerinde bu kesimler için cesaretlendirici önlemler alınmalıdır. Çiftçiler, daha fazla gelir elde etmeyi bekledikleri durumlarda yeni yatırımlara karar vermekte daha cesur davranmaktadırlar. Bu nedenle hibe uygulamalarının beklenen sonuçlarının, yatırıma temkinli yaklaşan yoksullar için çok daha anlaşılır ve güvenilir şekilde anlatımı önemlidir. Böylece, hedeflenen yoksul kesimlerin daha girişimci tutum almaları beklenebilir.

Çiftçilerin bilgi kaynaklarındaki farklılığın istatistiksel olarak önemli çıkması, tarımsal yayımın önemine işaret etmektedir. Programların öncesinde etkili bir yayım faaliyetinin hayata geçirilmesi hibe uygulamalarının başarıya ulaşmasında olumlu katkıda bulunacaktır. Bu amaçla hazırlanacak yayım programlarında;

- Kadınların tanıtım toplantıları ve eğitimlere katılımını artıracak düzenlemeler yapılmalıdır. Bu düzenlemelerde özellikle yöreye göre, toplantı saati ve günün ayarlanması şeklinde olabileceği gibi gerekirse kadınlar için ayrı toplantılarda düzenlenmesi şeklinde de düşünülmelidir.

- Hibe duyurusunu ilan etmenin ilk adım olduğu gerçeği unutulmamalıdır. Programların bir yenilik içerdiği ve yeniliğin benimsenmesinin bir süreç olarak ele alınması gerektiği göz önüne alınmalıdır ve yayım programlarının süresi buna uygun düşünülmelidir. 
- Yeniliğin kabulü ve yatırımın yapılması sonucu beklenen gelir konusunda ayrıntılı bilgi verilmeli, tüm detaylar çiftçilerin bu konudaki tereddütlerini giderecek şekilde açıklanmalıdır.

- Sürecin her aşamasında çiftçilerin programlara ilişkin doğru bilgiye ulaşabilmesi için, etkin iletişim kanalları oluşturulmalı ve sürekli açık tutulmalıdır.

- Özel tarım danışmanları yayım programının bir paydaşı olarak kabul edilmeli ve programı uygulayan kurumlar ile birlikte hareket etmeleri için zeminler oluşturulmalıdır.

\section{Kaynaklar}

Akkoyun, H., 2018. AB Tarım hibelerinin Rostow kalkınma modeline göre etkileri Denizli ili örneği. Yüksek Lisans Tezi. Atılım Üniversitesi Sosyal Bilimleri Enstitüsü Kamu Yönetimi ve Siyaset Bilimi Anabilim Dalı, 168s, Ankara.

Alnıçı, M., 2015. SEKP süt stratejik yatırım planı hibe programının değerlendirilmesi. Yüksek Lisans Tezi. Gaziosmanpaşa Üniversitesi Fen Bilimleri Enstitüsü Tarım Ekonomisi Anabilim Dalı, 182s, Tokat.

Çağlar, O., 2019. Kırsal kalkınma yatıımlarının desteklenmesi programı kapsamında makine ekipman hibe programının Erzurum ili örneğinde değerlendirilmesi. Yüksek Lisans Tezi. Atatürk Üniversitesi Fen Bilimleri Enstitüsü Tarım Makinaları Anabilim Dalı, 88s, Erzurum.

Çobanoğlu, F., Cankurt, M., Tunalığlu, R., Yılmaz, H., Nalbantoğlu, A., 2017. Kırsal kalkınma yatırımlarının desteklenmesi programının etkisinin değerlendirilmesi: Bursa ili örneği. Tekirdağ Ziraat Fakültesi Dergisi, 14 (1): 16-27.

Demirbük, M., 2013. Kırsal kalkınma yatırımlarının desteklenmesi programının değerlendirilmesi Sivas ili örneği. Yüksek Lisans Tezi. Gaziosmanpaşa Üniversitesi Fen Bilimleri Enstitüsü Tarım Ekonomisi Anabilim Dalı, 86s, Tokat.

Demirbük, M., Kızılaslan, N., 2020. Islah amaçlı yetiştirici birlikleri ile üyeleri arasındaki ilişkilerin analizi: Sivas ili örneği. KSÜ Tarım ve Doğa Dergisi, 23 (1): 194-211. DOI: 10.18016/ ksutarimdoga.vi.562087.

Diiro., G.M., Sam, A.G., 2015. Agricultural technology adoption and nonfarm earnings in Uganda: a semiparametric analysis. The Journal of Developing Areas, 49 (2), 145-162. doi:10.1353/jda.2015.0013.

Howley, P., Donoghu,e O.C., Heanue, K., 2012. Factors affecting farmers' adoption of agricultural innovations: a panel data analysis of the use of artificial insemination among dairy farmers in ireland. Journal of Agricultural Science, 4 (6): 171-180

Keleş, OC., 2018. Trabzon ilinde IPARD programı kapsamındaki arıcılık hibelerinin etkinliğinin belirlenmesi. Yüksek Lisans Tezi. Atatürk Üniversitesi Fen Bilimleri Enstitüsü Tarım Ekonomisi Anabilim Dalı, 69s, Erzurum.

Kılıçtek, S., Aksoy, A., 2019. Erzurum ili süt sığırcılığı işletmelerinin yenilikleri benimseme açısından değerlendirilmesi. Türk Tarım ve Doğa Bilimleri Dergisi, 6 (3): 424-431. DOI: 10.30910/turkjans.595216

Kırsal Kalkınma Yatıımlarının Desteklenmesi Programı Kapsamında Makine ve Ekipman Alımlarının Desteklenmesi Hakkında Tebliğ (2013, 26 Haziran). Resmî Gazete (sayı 28689), https://www.resmigazete.gov.tr/eskiler/2013/06/20130626-31.htm (Erişim tarihi: 20 Mart 2020).

Lefebvre, M., De Cuyper, K., Loix, E., Viaggi, D., Gomez-y-Paloma, S., 2014. European farmers' intentions to invest in 2014-2020: survey results, JRC Science and Policy Reports, Publications Office of the European Union, 100p, Luxembourg.

Melesse, B., 2018. A review on factors affecting adoption of agricultural new technologies in Ethiopia. J Agri Sci Food Res 9(3): 226-231.

Nwibo, S.U., Alimba, J.O., 2013. Determinants of investment decisions among agribusiness investors in south east, Nigeria. Journal of Business and Management. 8(6): 60 - 67.

Olsen, VJ., Lund, M., 2009. Incentives and socioeconomic factors influencing investment behavior in agriculture. 17th International Farm Management Congress, Volume I, 503-517, July 19-24, Bloomington/Normal, Illinois, USA.

Palaz, S., Boz, İ., 2008. Üniversite mezunu yetişkinlerin farklı organizasyonlarda gönüllü hizmet vermesini etkileyen faktörler. Balıkesir Üniversitesi Sosyal Bilimler Enstitüsü Dergisi, 11 (19):95-106.

Pannell, D.J., Marshall, G.R., Barr, N., Curtis, A., Vanclay, F., Wilkinson, R., 2006. Understanding and promoting adoption of conservation practices by rural landholders. Australian Journal of Experimental Agriculture, 46, 1407-1424. http://dx.doi.org/10.1071/EA05037 
Sezgin, A., Erem Kaya, T., Kumbasaroğlu, H., Külekçi, M., 2010. Tarımsal Yeniliklerin Benimsenmesinde Etkili Olan Faktörlerin Analizi: Erzurum İli Örneği. Şanlıurfa,Türkiye. Türkiye IX. Tarım Ekonomisi Kongresi, 22-24 Eylül, 2010, Harran Üniversitesi Ziraat Fakültesi. Şanlıurfa. s. 557-564.

Ton, G., de Grip, K., Klerkx, L., Rau, M-L., Douma, M., Friis-Hansen, E., Triomphe, B., Waters- Bayer, A., Wongtschowski, M., 2013. Effectiveness of innovation grants to smallholder agricultural producers: an explorative systematic review. EPPI-Centre, Social Science Research Unit, Institute of Education, University of London.

Yolal, A.K., 2019. Basınçlı sulama sistemleri hibe destek uygulamalarının değerlendirilmesi Yozgat ili örneği. Yüksek Lisans Tezi. Kahramanmaraş Sütçü İmam Üniversitesi Fen Bilimleri Enstitüsü Biyosistem Mühendisliği Anabilim Dalı, 45s, Kahramanmaraş. 